\title{
MODEL ECONOMIC ORDER QUANTITY (EOQ) DAN MODEL OPTIMISASI ROBUST DALAM PENENTUAN PERSEDIAAN ALAT SUNTIK (SPUIT)
}

\author{
Putri Bella Sagita $^{1 \S}$, Ni Ketut Tari Tastrawati ${ }^{2}$, Kartika Sari $^{3}$ \\ ${ }^{1}$ Program Studi Matematika, Fakultas MIPA - Universitas Udayana [Email: putribellasagita1103@ gmail.com] \\ ${ }^{2}$ Program Studi Matematika, Fakultas MIPA - Universitas Udayana [Email: tastrawati@unud.ac.id] \\ ${ }^{3}$ Program Studi Matematika, Fakultas MIPA - Universitas Udayana [Email: sarikaartika@unud.ac.id] \\ ${ }^{\S}$ Corresponding Author
}

\begin{abstract}
The purpose of this research is to determine and analyze the minimum order quantities and the supply cost through Economic Order Quantity (EOQ) Model without Stock Out, EOQ Model with Buffer Stock, and Robust Optimization. EOQ model without Stock Out is an inventory model with a fixed number of requests and a fixed period of demand so the goods are considered always available or there is no stock out. Whereas EOQ Model with Buffer Stock is an inventory model with uncertainty demand during the lead time that described with a uniform density function. Another model is Robust Optimization Model that is used for cases with uncertainty demand. The results showed that the minimum order quantities through EOQ Model without Stock Out and EOQ Model with Buffer Stock was almost the same value but the cost was more minimum with the EOQ Model with Buffer Stock. Whereas, through the Robust Optimization Model there are different minimum order quantities for each period with a minimum supply cost compared to the two previous models. This occurs in both types of Spuit, namely Spuit Terumo $3 \mathrm{~mL}$ and Spuit Terumo $5 \mathrm{~mL}$.
\end{abstract}

Keywords: EOQ, Inventory Model, Optimization Robust, Syringe

\section{PENDAHULUAN}

Pelayanan medis di suatu rumah sakit tentu berkaitan erat dengan persediaan alat-alat medis, salah satunya yaitu alat suntik (spuit). Spuit memiliki beberapa ukuran yaitu $1 \mathrm{~mL}, 3 \mathrm{~mL}, 5$ $\mathrm{mL}, 10 \mathrm{~mL}, 20 \mathrm{~mL}$, dan $50 \mathrm{~mL}$ dengan masingmasing ukuran memiliki fungsi yang berbeda (Bahtiyar, 2015). Jumlah pemakaian alat suntik (spuit) di suatu rumah sakit setiap hari bukanlah dalam jumlah yang sedikit.

Hal ini dirasakan pula oleh Rumah Sakit Umum Surya Husadha sebagai salah satu rumah sakit swasta yang terletak di pusat kota Denpasar. Berdasarkan hasil wawancara dengan pihak Depo Farmasi RSU Surya Husadha, diketahui bahwa alat suntik yang paling banyak digunakan dalam satu tahun terakhir yaitu Spuit Terumo $3 \mathrm{~mL}$ dengan rata-rata pemakaian sebanyak 113 unit/hari dan Spuit Terumo $5 \mathrm{~mL}$ dengan rata-rata pemakaian sebanyak 155 unit/hari. Selama ini, pihak RSU Surya Husadha belum menggunakan metode apapun dalam perencanaan persediaan di setiap bulannya. Untuk itu, dibutuhkan perencanaan persediaan yang tepat agar tidak terjadi kekurangan (stock out) maupun kelebihan (over stock).

Beberapa model yang dapat digunakan dalam masalah persediaan yaitu Economic Order Quantity (EOQ) (Haming, et al., 2017) dan Optimisasi Robust (Bertsimas \& Thiele, 2006). Berdasarkan jumlah permintaan, model EOQ dapat dibagi menjadi dua yaitu EOQ Deterministik (permintaan diasumsikan tetap) dan EOQ Probabilistik (permintaan berubahubah). Model EOQ Deterministik terdiri dari Model EOQ tanpa Stock Out dan Model EOQ dengan Stock Out. Model EOQ Probabilistik terdiri dari Model EOQ dengan Permintaan Tidak Tetap, Model EOQ dengan Cadangan Penyangga (buffer stock) (Siagian, 2006).

Model EOQ tanpa Stock Out merupakan model persediaan dengan jumlah permintaan tetap dan periode waktu permintaan tetap 
sehingga barang dianggap selalu tersedia saat dibutuhkan atau tidak terjadi stock out. Sedangkan, Model EOQ dengan Cadangan Penyangga (buffer stock) merupakan model persediaan dengan permintaan tidak tentu selama masa tenggang yang dijabarkan dengan fungsi densitas uniform (Siagian, 2006). Model lainnya yang dapat diterapkan yaitu Optimisasi Robust yang digunakan untuk ketidakpastian permintaan. Alasan ketidakpastian (uncertainty) itu dapat disebabkan oleh kesalahan pengukuran atau tidak tersedianya informasi yang diperlukan dalam proses perhitungan (Ben-Tal, et al., 2009).

Adapun tujuan dari penelitian ini yaitu menentukan serta menginterpretasi jumlah pemesanan minimum dan biaya penyediaan alat suntik melalui model Economic Order Quantity (EOQ) dan Optimisasi Robust.

\section{METODE PENELITIAN}

\section{Jenis dan Sumber Data}

Data yang digunakan dalam penelitian ini adalah data kuantitatif berupa data historis pemakaian alat suntik (spuit) Terumo $3 \mathrm{~mL}$ dan Terumo $5 \mathrm{~mL}$ di RSU Surya Husadha selama 1 tahun terakhir dari bulan November 2017 hingga Oktober 2018. Selain itu, data yang digunakan adalah data biaya pengadaan, biaya penyimpanan, biaya kekurangan, dan biaya pembelian yang dikeluarkan oleh rumah sakit tersebut. Data diperoleh dari pihak rumah sakit berupa catatan yang didokumentasi.

\section{Metode Analisis Data}

Adapun langkah pertama yang dilakukan sebelum menganalisis data yaitu mencari data historis jumlah pemakaian alat suntik (spuit) Terumo $3 \mathrm{~mL}$ dan Terumo $5 \mathrm{~mL}$ selama 1 tahun terakhir beserta biaya pengadaan, biaya penyimpanan, biaya kekurangan, dan biaya pembelian yang telah dikeluarkan oleh Rumah Sakit Umum Surya Husadha.

Selanjutnya, data dianalisis menggunakan Model Economic Order Quantity (EOQ) tanpa Stock Out dengan menghitung jumlah pemesanan minimum $(q)$ yang merujuk pada $q=\sqrt{\frac{2 K d}{T h}}$ dan biaya penyediaan $(c(q))$ yang merujuk pada $c(q)=\frac{T q h}{2}+\frac{K d}{q}+c d$.
Setelah itu, dilakukan analisis data menggunakan Model Economic Order Quantity (EOQ) dengan Cadangan Penyangga. Jumlah pemesanan minimum $(q)$ dihitung dengan langkah-langkah:

1. Menghitung $q$ dengan menggunakan persamaan $q=\sqrt{\frac{2 K d}{T h}} ;$

2. menghitung $R$ melalui persamaan $\int_{R}^{\infty} f(l) d l=\frac{h q}{p d}$ dimana $q$ merupakan hasil perhitungan pada langkah (1);

3. menghitung $q$ melalui persamaan $q=\sqrt{\frac{2 K d+2 p d\left(\int_{R}^{\infty}(l-R) f(l) d l\right)}{h}}$ dimana $R$ merupakan hasil perhitungan pada langkah (2);

4. menghitung $R$ dengan mensubstitusikan $q$ yang diperoleh di langkah (3) pada persamaan di langkah (2);

5. ulangi langkah (3) dan (4) hingga diperoleh nilai $q$ dan $R$ pada iterasi ke- $i$ dan $i+1$ yang mendekati satu nilai tertentu.

Selanjutnya, menghitung biaya penyediaan $(c(q))$ dengan merujuk pada persamaan

$$
\begin{aligned}
c(q)= & h\left(\frac{q}{2}+(R-\bar{l})\right)+\frac{K d}{q}+\frac{p d}{q} \\
& \left(\int_{R}^{\infty}(l-R) f(l) d l\right)+c d .
\end{aligned}
$$

Kemudian, data dianalisis menggunakan Model Optimisasi Robust dengan langkahlangkah berikut:

1. menghitung mean dan standar deviasi dari $d_{k}$

2. menghitung $z_{k}$ dengan merujuk pada persamaan $z_{k}=\frac{d_{k}-\bar{d}_{k}}{\hat{d}_{k}}$;

3. menyelidiki apakah $z_{k}$ telah memenuhi kendala $\quad \sum_{k=0}^{t-1}\left|z_{k}\right| \leq \Gamma ; 0 \leq z_{k} \leq 1$. Jika belum, maka dicari solusi optimal dengan merujuk pada persamaan $\max \sum_{k=0}^{t-1} \hat{d}_{k} z_{k}$ sehingga nilai $z_{k}$ memenuhi kendala $\sum_{k=0}^{t-1}\left|z_{k}\right| \leq \Gamma \quad ; 0 \leq z_{k} \leq 1$

4. setelah memperoleh solusi optimal, maka akan dihitung nilai $\bar{d}_{k}$ dari setiap periode $k$ dengan menggunakan rumus $\bar{d}_{k}=d_{k}-$ $\hat{d}_{k} z_{k}$

5. membentuk fungsi objektif dan fungsi kendala untuk kasus persediaan alat suntik sebagai berikut:

$$
\min \sum_{k=0}^{t-1}\left(c q_{k}+K v_{k}+y_{k}\right)
$$


dengan kendala:

$y_{k} \geq h\left(x_{0}+\sum_{k=0}^{t-1}\left(u_{k}-\bar{d}_{k}\right)+q_{k} \Gamma_{k}+\sum_{k=0}^{t-1} r_{k}\right)$

$y_{k} \geq p\left(-x_{0}-\sum_{k=0}^{t-1}\left(u_{k}-\bar{d}_{k}\right)+q_{k} \Gamma_{k}+\sum_{k=0}^{t-1} r_{k}\right)$

$q_{k}+r_{k} \geq \hat{d}_{k} ; q_{k} \geq 0, r_{k} \geq 0$

$0 \leq u_{k} \leq M v_{k} ; \quad v_{k} \in\{0,1\}$

$u_{k} \leq d \quad ; k=0,1, \ldots, t-1$

$x_{0}+\sum_{k=0}^{t-1}\left(u_{k}-\bar{d}_{k}\right)+q_{k} \Gamma_{k}+\sum_{k=0}^{t-1} r_{k} \leq G ;$

6. menghitung jumlah pemesanan $\left(q_{k}\right)$, variabel biner 0 atau $1\left(v_{k}\right)$, biaya penyimpanan dan kekurangan barang $\left(y_{k}\right)$, variabel $u_{k}$, dan variabel $r_{k}$ dari fungsi objektif dan kendala pada langkah 5 dengan bantuan software MATLAB.

Terakhir, menginterpretasi hasil perhitungan jumlah pemesanan minimum dan total biaya penyediaan dengan model Economic Order Quantity (EOQ) dan Optimisasi Robust.

\section{HASIL DAN PEMBAHASAN}

Data historis pemakaian alat suntik (spuit) Terumo dari bulan November 2017 sampai dengan Oktober 2018 disajikan pada Tabel 1.

Tabel 1. Data Historis Pemakaian Spuit Terumo

\begin{tabular}{|c|c|c|c|}
\hline \multirow[b]{2}{*}{ Tahun } & \multirow[b]{2}{*}{ Bulan } & \multicolumn{2}{|c|}{ Jumlah Pemakaian (unit) } \\
\hline & & $\begin{array}{c}\text { Spuit Terumo } \\
3 \mathrm{~mL}\end{array}$ & $\begin{array}{c}\text { Spuit Terumo } \\
5 \mathrm{~mL}\end{array}$ \\
\hline \multirow{2}{*}{2017} & November & 3.538 & 4.626 \\
\hline & Desember & 3.441 & 4.687 \\
\hline \multirow{10}{*}{2018} & Januari & 4.037 & 5.318 \\
\hline & Februari & 3.271 & 4.392 \\
\hline & Maret & 3.204 & 4.013 \\
\hline & April & 3.598 & 4.665 \\
\hline & Mei & 3.227 & 4.811 \\
\hline & Juni & 3.093 & 4.715 \\
\hline & Juli & 3.320 & 4.682 \\
\hline & Agustus & 3.096 & 4.599 \\
\hline & September & 2.968 & 4.187 \\
\hline & Oktober & 4.035 & 5.112 \\
\hline \multicolumn{2}{|c|}{ Jumlah } & 40.828 & 55.807 \\
\hline
\end{tabular}

Sumber: RSU Surya Husadha (2018)

Dengan biaya-biaya persediaan, antara lain:

a. Biaya Pembelian untuk Spuit Terumo $3 \mathrm{~mL}$ adalah Rp 5.031/unit dan Spuit Terumo 5 $\mathrm{mL}$ adalah Rp 6.160/unit. b. Biaya Pengadaan untuk Spuit Terumo $3 \mathrm{~mL}$ dan Spuit Terumo $5 \mathrm{~mL}$ diasumsikan sama yaitu sebesar Rp 49.156.

c. Biaya Penyimpanan untuk masing-masing Spuit diasumsikan sama sebesar Rp 500/unit/tahun.

d. Biaya Kekurangan sebesar Rp 5.036/unit/tahun untuk Spuit Terumo $3 \mathrm{~mL}$ dan $\mathrm{Rp}$ 3.530/unit/tahun untuk Spuit Terumo $5 \mathrm{~mL}$.

\subsection{Pengolahan Data dengan Model EOQ tanpa Stock Out}

Berdasarkan data pada Tabel 1, diketahui bahwa jumlah pemakaian Spuit Terumo $3 \mathrm{~mL}$ dan Spuit Terumo $5 \mathrm{~mL}$ selama satu tahun $(d)$ adalah 40.828 unit dan 55.807 unit. Selanjutnya, dihitung jumlah pemesanan minimum $(q)$, banyaknya pemesanan $(N)$, jarak antar pesanan $(t)$ dan total biaya penyediaan $(c(q))$ Spuit Terumo $3 \mathrm{~mL}$ dan Spuit Terumo 5 $\mathrm{mL}$ dengan model EOQ tanpa Stock Out.

\subsubsection{Spuit Terumo $3 \mathrm{~mL}$}

Pertama, dihitung jumlah pemesanan minimum $(q)$ yaitu $q=\sqrt{\frac{2 K d}{T h}}$. Berdasarkan data historis dan data biaya-biaya persediaan, diketahui biaya pengadaan $(K)=\operatorname{Rp} 49.156$, periode $(T)=1$ tahun, biaya penyimpanan $(h)=\mathrm{Rp} 500$, dan biaya pembelian $(c)=$ Rp 5.031, sehingga didapat jumlah pemesanan minimum

$$
\begin{aligned}
q & =\sqrt{\frac{2 K d}{T h}} \\
& =\sqrt{\frac{2 \times 49.156 \times 40.828}{1 \times 500}} \\
& =2.833,33
\end{aligned}
$$

Dengan demikian, diperoleh $q$ untuk Spuit Terumo $3 \mathrm{~mL}$ sebanyak $2.833,33 \approx 2.834$ unit. Setelah memperoleh $q$, selanjutnya dicari banyaknya pemesanan $(N)$, jarak antar pesanan $(t)$, dan biaya penyediaan $(c(q))$. Dari sini didapat hasil sebesar:

$$
\begin{array}{rlrl}
N=\frac{d}{q} & t & =\frac{T}{N} \\
& =\frac{40.828}{2.834} & & \frac{1}{15} \\
& =14,40 \approx 15 \mathrm{kali} & & =0,067 \text { tahun } \\
& =24,455 \text { hari } \\
& \approx 25 \text { hari }
\end{array}
$$


dan

$$
\begin{aligned}
& c(q)=\frac{T q h}{2}+\frac{K d}{q}+c d \\
& =\frac{1 \times 2.834 \times \operatorname{Rp~} 500}{2}+\frac{\operatorname{Rp~} 49.156 \times 40.828}{2.834} \\
& \quad+(\operatorname{Rp} 5.031 \times 40.828)
\end{aligned}
$$$$
=\operatorname{Rp} 206.822 .333,55
$$

Dengan demikian, diperoleh $q$ untuk Spuit Terumo $3 \mathrm{~mL}$ sebanyak 2.834 unit dengan pemesanan sebanyak 15 kali per tahun dan jarak antar pesanan 25 hari. Selain itu, diperoleh biaya penyediaan yang dikeluarkan selama periode tersebut sebesar Rp 206.822.333,55.

\subsubsection{Spuit Terumo $5 \mathrm{~mL}$}

Perhitungan untuk Spuit Terumo $5 \mathrm{~mL}$ analog dengan perhitungan pada subbab 3.1.1. Dengan demikian, diperoleh $q$ untuk Spuit Terumo $5 \mathrm{~mL}$ sebanyak 3.313 unit dengan pemesanan sebanyak 17 kali per tahun dan jarak antar pesanan 22 hari. Selain itu, diperoleh biaya penyediaan yang dikeluarkan selama periode tersebut sebesar Rp 345.427.395,62.

\subsection{Pengolahan Data dengan Model EOQ dengan Cadangan Penyangga (Buffer Stock)}

Berdasarkan data pada Tabel 1, diketahui bahwa jumlah pemakaian Spuit Terumo $3 \mathrm{~mL}$ dan Spuit Terumo $5 \mathrm{~mL}$ selama satu tahun $(d)$ adalah 40.828 unit dan 55.807 unit. Selanjutnya, dihitung jumlah pemesanan minimum $(q)$ dan total biaya penyediaan $(c(q))$ Spuit Terumo $3 \mathrm{~mL}$ dan Spuit Terumo $5 \mathrm{~mL}$ dengan model EOQ dengan Cadangan Penyangga (Buffer Stock). Selain itu, pihak rumah sakit mengasumsikan jumlah pemakaian Spuit Terumo $3 \mathrm{~mL}$ selama waktu tenggang (lead time) berkisar antara 226 unit $\leq x \leq$ 340 unit sedangkan jumlah pemakaian Spuit Terumo $5 \mathrm{~mL}$ berkisar antara 310 unit $\leq x \leq$ 466 unit. Sehingga, jumlah pemakaian selama lead time untuk Spuit Terumo $3 \mathrm{~mL}\left(s_{3}\right)$ dan Spuit Terumo $5 \mathrm{~mL}\left(s_{5}\right)$ berturut-turut memiliki fungsi densitas peluang sebagai berikut:

$$
\begin{aligned}
& f\left(s_{3}\right)=\left\{\begin{array}{rcc}
\frac{1}{114} & ; & 226 \leq x \leq 340 \\
0 & ; & x \text { lainnya }
\end{array}\right. \\
& f\left(s_{5}\right)=\left\{\begin{array}{rcc}
\frac{1}{156} & ; & 310 \leq x \leq 466 \\
0 & ; & x \text { lainnya }
\end{array}\right.
\end{aligned}
$$

dengan mean :

$$
\begin{aligned}
\bar{s}_{3} & =\frac{a_{3}+b_{3}}{2} \\
& =\frac{226+340}{2} \\
& =283 \text { unit }
\end{aligned}
$$

$$
\begin{aligned}
\bar{s}_{5} & =\frac{a_{5}+b_{5}}{2} \\
& =\frac{310+466}{2} \\
& =388 \text { unit }
\end{aligned}
$$

Selanjutnya, dihitung jumlah pemesanan minimum $(q)$ dan total biaya penyediaan $(c(q))$ untuk Spuit Terumo $3 \mathrm{~mL}$ dan Spuit Terumo 5 $\mathrm{mL}$.

\subsubsection{Spuit Terumo $3 \mathrm{~mL}$}

Sebelum menghitung $q$ dan $c(q)$ untuk Spuit Terumo $3 \mathrm{~mL}$, dihitung terlebih dahulu Reorder Point $(R)$ yang sesuai dengan data Spuit Terumo $3 \mathrm{~mL}$.

$$
\begin{aligned}
& \int_{R}^{\infty} f\left(s_{3}\right) d s_{3}=\frac{h q}{p d} \\
& \Leftrightarrow \int_{R}^{114} \frac{1}{114} d s_{3}=\frac{500 \times q}{5.036 \times 40.828} \\
& \Leftrightarrow 114 \times\left(1-\frac{500 \times q}{5.036 \times 40.828}\right)=R
\end{aligned}
$$

Selanjutnya, dihitung jumlah pemesanan minimum $(q)$ diperoleh:

$q=\sqrt{\frac{2 K d+2 p d\left(\int_{R}^{\infty}\left(s_{3}-R\right) f\left(s_{3}\right) d l\right)}{h}}$

Sebelum menjabarkan persamaan (3.2), terlebih dahulu akan dihitung

$$
\begin{aligned}
\int_{R}^{\infty}\left(s_{3}-R\right) f\left(s_{3}\right) d s_{3} & =\int_{R}^{114}\left(s_{3}-R\right) \frac{1}{114} d s_{3} \\
& =57-R+\frac{1}{228} R^{2}(3.3)
\end{aligned}
$$

Dengan demikian, persamaan (3.2) dapat ditulis sebagai berikut:

$q=\sqrt{\frac{(2 \times 49.156 \times 40.828)+(2 \times 5.036 \times 40.828)\left(57-R+\frac{1}{228} R^{2}\right)}{500}}$

Lebih lanjut lagi, dihitung $q$ dengan menggunakan persamaan $q=\sqrt{\frac{2 K d}{T h}}$. 
Berdasarkan hasil yang didapat sebelumnya pada Model EOQ tanpa Stock Out, diperoleh $q$ sebesar 2.834 unit. Setelah nilai $q$ diperoleh, maka dihitung besarnya $R$ dengan menggunakan persamaan (3.1).

$$
\begin{aligned}
R & =114 \times\left(1-\frac{500 \times q}{5.036 \times 40.828}\right) \\
& =114 \times\left(1-\frac{500 \times 2.834}{5.036 \times 40.828}\right) \\
& =113,21 \text { unit }
\end{aligned}
$$

Dari sini, dihitung kembali besarnya $q$ dengan merujuk pada persamaan (3.4) diperoleh $q=2.833,73$ unit. Demikian seterusnya sehingga diperoleh hasil perhitungan seperti pada Tabel 2.

Tabel 2. Nilai q dan R Pada Setiap Iterasi

\begin{tabular}{|c|c|c|}
\hline Iterasi $(i)$ & $q$ & $R$ \\
\hline 1 & 2.833 & 113,21 \\
\hline 2 & $2.833,73$ & 113,21 \\
\hline 3 & $2.833,73$ & 113,21 \\
\hline
\end{tabular}

Sumber: Data diolah (2019)

Terlihat pada Tabel 2 bahwa nilai $q$ dan $R$ telah mendekati satu nilai tertentu sehingga jumlah pemesanan minimum diperoleh saat $q=2.833,73 \approx 2.834$ unit dan titik pemesanan kembali dilakukan ketika persediaan mencapai $113,21 \approx 113$ unit. Adapun biaya penyediaan $(c(q))$ selama satu tahun diperoleh hasil sebesar

$$
\begin{aligned}
c(q)= & h\left(\frac{q}{2}+\left(R-\bar{s}_{3}\right)\right)+\frac{K d}{q} \\
& +\frac{p d}{q}\left(\int_{R}^{\infty}\left(s_{3}-R\right) f\left(s_{3}\right) d s_{3}\right)+c d \\
= & \operatorname{Rp~} 500\left(\frac{2.834}{2}+(113-283)\right) \\
& +\frac{\operatorname{Rp~} 49.156 \times 40.828}{2.834} \\
& +\frac{\operatorname{Rp~} 5.036 \times 40.828}{2.834}\left(57-113+\frac{1}{228}(113)^{2}\right) \\
& +(\operatorname{Rp~} 5.031 \times 40.828) \\
= & \operatorname{Rp~} 206.737 .651,75631
\end{aligned}
$$

Jadi, diperoleh biaya penyediaan $(c(q))$ selama satu tahun sebesar Rp 206.737.651,75631.

\subsubsection{Spuit Terumo $5 \mathrm{~mL}$}

Perhitungan untuk Spuit Terumo $5 \mathrm{~mL}$ analog dengan perhitungan pada subbab 3.2.1. Nilai $q$ dan $R$ dihitung dan iterasi dihentikan saat nilai $q$ dan $R$ pada iterasi ke- $i$ dan $i+1$ mendekati satu nilai tertentu. Sehingga diperoleh hasil perhitungan seperti pada Tabel 3 .
Tabel 3. Nilai q dan R Pada Setiap Iterasi

\begin{tabular}{|c|c|c|}
\hline Iterasi $(i)$ & $q$ & $R$ \\
\hline 1 & 3.313 & 154,69 \\
\hline 2 & $3.313,20$ & 154,69 \\
\hline 3 & $3.313,20$ & 154,69 \\
\hline
\end{tabular}

Sumber: Data diolah (2019)

Terlihat pada Tabel 3 bahwa nilai $q$ dan $R$ telah mendekati satu nilai tertentu sehingga jumlah pemesanan minimum diperoleh saat $q=3.313,20 \approx 3.314$ unit dan titik pemesanan kembali dilakukan ketika persediaan mencapai $154,69 \approx 155$ unit. Adapun biaya penyediaan $(c(q))$ selama satu tahun diperoleh hasil sebesar Rp 345.311.086,29393.

\subsection{Pengolahan Data dengan Model Optimisasi Robust}

Berdasarkan data pada Tabel 1 beserta biaya-biaya persediaan dari pihak rumah sakit, dihitung jumlah pemesanan minimum dan total biaya penyediaan Spuit Terumo $3 \mathrm{~mL}$ dan Spuit Terumo $5 \mathrm{~mL}$ melalui model Optimisasi Robust.

\subsubsection{Spuit Terumo $3 \mathrm{~mL}$}

Berdasarkan data historis pemakaian Spuit Terumo $3 \mathrm{~mL}$ seperti pada Tabel 1, dicari terlebih dahulu nilai tengah $\left(\bar{d}_{k}\right)$ dari $d_{k}$ diperoleh hasil sebagai berikut:

$\bar{d}_{k}=\frac{\sum_{k=0}^{11} d_{k}}{12}=\frac{40.828}{12}=3.402,33$

Selanjutnya, dihitung standar deviasi $\left(\hat{d}_{k}\right)$ dari $d_{k}$. Untuk menghitung $\hat{d}_{k}$, terlebih dahulu dihitung $\sum_{k=0}^{11}\left(d_{k}-\bar{d}_{k}\right)^{2}$ seperti pada Tabel 4 .

Tabel 4. Hasil Perhitungan $\sum_{k=0}^{11}\left(d_{k}-\bar{d}_{k}\right)^{2}$

\begin{tabular}{|c|c|c|c|}
\hline $\mathrm{K}$ & $d_{k}$ & $d_{k}-\bar{d}_{k}$ & $\left(d_{k}-\bar{d}_{k}\right)^{2}$ \\
\hline 0 & 3.538 & 135,67 & $18.406,3489$ \\
\hline 1 & 3.441 & 38,67 & $1.495,3689$ \\
\hline 2 & 4.037 & 634,67 & $402.806,0089$ \\
\hline 3 & 3.271 & $-131,33$ & $17.247,5689$ \\
\hline 4 & 3.204 & $-198,33$ & $39.334,7889$ \\
\hline 5 & 3.598 & 195,67 & $38.286,7489$ \\
\hline 6 & 3.227 & $-175,33$ & $30.740,6089$ \\
\hline 7 & 3.093 & 309,33 & $95.685,0489$ \\
\hline 8 & 3.320 & $-82,33$ & $6.778,2289$ \\
\hline 9 & 3.096 & $-306,33$ & $93.838,0689$ \\
\hline 10 & 2.968 & $-434,33$ & $188.642,5489$ \\
\hline 11 & 4.035 & 632,67 & $400.271,3289$ \\
\hline \multicolumn{3}{|c|}{$\sum_{k=0}^{11}\left(d_{k}-\bar{d}_{k}\right)^{2}$} & $1.333 .532,6668$ \\
\hline
\end{tabular}

Sumber: Data diolah (2019) 
Dengan demikian, diperoleh:

$$
\begin{aligned}
\hat{d}_{k} & =\sqrt{\frac{\sum_{k=0}^{11}\left(d_{k}-\bar{d}_{k}\right)^{2}}{11}} \\
& =\sqrt{\frac{1.333 .532,6668}{11}} \\
& =348,18
\end{aligned}
$$

Selanjutnya, dihitung scaled deviation $\left(z_{k}\right)$ dari $d_{k}$ dengan merujuk pada persamaan $z_{k}=\frac{d_{k}-\bar{d}_{k}}{\hat{d}_{k}}$. Hasil perhitungan dapat dilihat pada Tabel 5.

Tabel 5. Perhitungan Nilai $\boldsymbol{z}_{\boldsymbol{k}}$

\begin{tabular}{|c|c|c|}
\hline$k$ & $d_{k}$ & $z_{k}$ \\
\hline 0 & 3.538 & 0,39 \\
\hline 1 & 3.441 & 0,11 \\
\hline 2 & 4.037 & 1,82 \\
\hline 3 & 3.271 & $-0,38$ \\
\hline 4 & 3.204 & $-0,57$ \\
\hline 5 & 3.598 & 0,56 \\
\hline 6 & 3.227 & $-0,50$ \\
\hline 7 & 3.093 & $-0,89$ \\
\hline 8 & 3.320 & $-0,24$ \\
\hline 9 & 3.096 & $-0,88$ \\
\hline 10 & 2.968 & $-1,25$ \\
\hline 11 & 4.035 & 1,82 \\
\hline
\end{tabular}

Sumber: Data diolah (2019)

Berdasarkan Tabel 5, diperoleh nilai $\sum_{k=0}^{11}\left|z_{k}\right|=9,41>1$. Selanjutnya, dicari nilai $z_{k}$ baru dengan merujuk pada:

$$
\max \sum_{k=0}^{11} \hat{d}_{k} z_{k}
$$

dengan kendala:

$$
\begin{gathered}
\sum_{k=0}^{11}\left|z_{k}\right| \leq 1 \\
0 \leq z_{k} \leq 1 \quad ; k=0, \ldots, 11
\end{gathered}
$$

Dengan demikian, diperoleh nilai $z_{k}$ seperti pada Tabel 6.

Setelah diperoleh $z_{k}$, dihitung $\bar{d}_{k}$ dari setiap $k$ dengan merujuk pada persamaan $\bar{d}_{k}=d_{k}-$ $\hat{d}_{k} z_{k}$, diperoleh hasil seperti pada Tabel 7 .
Tabel 6. Perhitungan Nilai $\boldsymbol{z}_{\boldsymbol{k}}$ dari Setiap $\boldsymbol{k}$

\begin{tabular}{|c|c|c|}
\hline$k$ & $d_{k}$ & $z_{k}$ \\
\hline 0 & 3.538 & 0,083333 \\
\hline 1 & 3.441 & 0,083333 \\
\hline 2 & 4.037 & 0,083333 \\
\hline 3 & 3.271 & 0,083333 \\
\hline 4 & 3.204 & 0,083333 \\
\hline 5 & 3.598 & 0,083333 \\
\hline 6 & 3.227 & 0,083333 \\
\hline 7 & 3.093 & 0,083333 \\
\hline 8 & 3.320 & 0,083333 \\
\hline 9 & 3.096 & 0,083333 \\
\hline 10 & 2.968 & 0,083333 \\
\hline 11 & 4.035 & 0,083333 \\
\hline
\end{tabular}

Sumber: Data diolah (2019)

Tabel 7. Perhitungan $\overline{\boldsymbol{d}}_{\boldsymbol{k}}$ dari Setiap $\boldsymbol{k}$

\begin{tabular}{|c|c|c|}
\hline$k$ & $z_{k}$ & $\bar{d}_{k}$ \\
\hline 0 & 0,083333 & 3.509 \\
\hline 1 & 0,083333 & 3.412 \\
\hline 2 & 0,083333 & 4.008 \\
\hline 3 & 0,083333 & 3.242 \\
\hline 4 & 0,083333 & 3.175 \\
\hline 5 & 0,083333 & 3.569 \\
\hline 6 & 0,083333 & 3.198 \\
\hline 7 & 0,083333 & 3.064 \\
\hline 8 & 0,083333 & 3.291 \\
\hline 9 & 0,083333 & 3.067 \\
\hline 10 & 0,083333 & 2.939 \\
\hline 11 & 0,083333 & 4.006 \\
\hline
\end{tabular}

Sumber: Data diolah (2019)

Selanjutnya, dibentuk fungsi tujuan dan fungsi kendala sebagai berikut:

$$
\begin{aligned}
& y_{k} \geq h\left(x_{0}+\sum_{k=0}^{11}\left(q_{k}-\bar{d}_{k}\right)+u_{k} \Gamma_{k}+\sum_{k=0}^{11} r_{k}\right) \\
& y_{k} \geq p\left(-x_{0}-\sum_{k=0}^{11}\left(q_{k}-\bar{d}_{k}\right)+u_{k} \Gamma_{k}+\sum_{k=0}^{11} r_{k}\right)
\end{aligned}
$$

$u_{k}+r_{k} \geq \hat{d}_{k} \quad ; u_{k} \geq 0, r_{k} \geq 0, k=0,1, \ldots, 11$

$0 \leq q_{k} \leq M v_{k} ; \quad v_{k} \in\{0,1\}$ dan $k=0,1, \ldots, 11$

$q_{k} \leq d \quad ; k=0,1, \ldots, 11$

$x_{0}+\sum_{k=0}^{11}\left(q_{k}-\bar{d}_{k}\right)+u_{k} \Gamma_{k}+\sum_{k=0}^{11} r_{k} \leq G$ 
Dengan bantuan software MATLAB, diperoleh hasil perhitungan variabel keputusan untuk setiap periodenya yang dapat dilihat pada Tabel 8 .

Tabel 8. Optimisasi Robust Spuit Terumo $3 \mathrm{~mL}$

\begin{tabular}{|c|c|c|c|c|c|}
\hline $\boldsymbol{k}$ & $\boldsymbol{q}_{\boldsymbol{k}}$ & $\boldsymbol{u}_{\boldsymbol{k}}$ & $\boldsymbol{r}_{\boldsymbol{k}}$ & $\boldsymbol{v}_{\boldsymbol{k}}$ & $\boldsymbol{y}_{\boldsymbol{k}}$ \\
\hline 0 & 0 & 348,18 & 0 & 0 & $\operatorname{Rp~669.598,2234}$ \\
\hline 1 & 2.707 & 348,18 & 0 & 1 & $\operatorname{Rp} 316.734,3219$ \\
\hline 2 & 4.008 & 348,18 & 0 & 1 & $\operatorname{Rp} 316.734,3219$ \\
\hline 3 & 3.242 & 348,18 & 0 & 1 & $\operatorname{Rp} 316.734,3219$ \\
\hline 4 & 3.175 & 348,18 & 0 & 1 & $\operatorname{Rp} 316.734,3219$ \\
\hline 5 & 3.569 & 348,18 & 0 & 1 & $\operatorname{Rp} 316.734,3219$ \\
\hline 6 & 3.198 & 348,18 & 0 & 1 & $\operatorname{Rp} 316.734,3219$ \\
\hline 7 & 3.064 & 348,18 & 0 & 1 & $\operatorname{Rp} 316.734,3219$ \\
\hline 8 & 3.291 & 348,18 & 0 & 1 & $\operatorname{Rp} 316.734,3219$ \\
\hline 9 & 3.067 & 348,18 & 0 & 1 & $\operatorname{Rp} 316.734,3219$ \\
\hline 10 & 2.939 & 348,18 & 0 & 1 & $\operatorname{Rp} 316.734,3219$ \\
\hline 11 & 4.006 & 347,18 & 1 & 1 & $\operatorname{Rp} 316.734,3219$ \\
\hline \multicolumn{5}{|c|}{ TOTAL } &
\end{tabular}

Sumber: Data diolah (2019)

Dengan demikian, diperoleh total biaya persediaan sebesar

$$
\begin{aligned}
& c(q)=\sum_{k=0}^{11}\left(c q_{k}+K v_{k}+y_{k}\right) \\
& =\left(\operatorname{Rp} 5.031 \times \sum_{k=0}^{11} q_{k}\right) \\
& +\left(\operatorname{Rp} 49.156 \times \sum_{k=0}^{11} v_{k}\right)+\sum_{k=0}^{11} y_{k} \\
& =\operatorname{Rp} 187.148 .637,76389113
\end{aligned}
$$

\subsubsection{Spuit Terumo $5 \mathrm{~mL}$}

Perhitungan untuk Spuit Terumo $5 \mathrm{~mL}$ analog dengan perhitungan pada subbab 3.3.1. Dengan bantuan software MATLAB, diperoleh hasil perhitungan variabel keputusan untuk setiap periodenya yang dapat dilihat pada Tabel 9.

Dengan demikian, diperoleh total biaya

\begin{tabular}{|c|c|c|c|c|c|}
\hline $\boldsymbol{k}$ & $q_{k}$ & $u_{k}$ & $r_{k}$ & $v_{k}$ & $y_{k}$ \\
\hline 0 & 0 & 354,49 & 0 & 0 & Rp 379.016,2609 \\
\hline 1 & 4.521 & 354,49 & 0 & 1 & Rp 310.509,9757 \\
\hline 2 & 5.289 & 354,49 & 0 & 1 & Rp 310.509,9757 \\
\hline 3 & 4.363 & 354,49 & 0 & 1 & $\operatorname{Rp} 310.509,9757$ \\
\hline 4 & 3.984 & 354,49 & 0 & 1 & Rp 310.509,9757 \\
\hline 5 & 4.636 & 354,49 & 0 & 1 & $\operatorname{Rp} 310.509,9757$ \\
\hline 6 & 4.782 & 354,49 & 0 & 1 & Rp 310.509,9757 \\
\hline 7 & 4.686 & 354,49 & 0 & 1 & 9757 \\
\hline 8 & 4.653 & 354,49 & 0 & 1 & $\mathrm{Rp} 31$ \\
\hline 9 & 4.570 & 354,49 & 0 & 1 & Rp 310.509,9757 \\
\hline 10 & 4.158 & 354,49 & 0 & 1 & Rp 310.509,9757 \\
\hline 11 & 0 & 353,49 & 1 & 0 & Rp 18.251.590,375 \\
\hline \multicolumn{5}{|c|}{ TOTAL } & $\operatorname{Rp} 21.735 .706,393$ \\
\hline
\end{tabular}
persediaan sebesar

$$
\begin{aligned}
c(q)= & \sum_{k=0}^{11}\left(c q_{k}+K v_{k}+y_{k}\right) \\
= & \left(\operatorname{Rp~} 6.160 \times \sum_{k=0}^{11} q_{k}\right) \\
& +\left(\operatorname{Rp~} 49.156 \times \sum_{k=0}^{11} v_{k}\right)+\sum_{k=0}^{11} y_{k} \\
= & \operatorname{Rp~303.381.986,3933302~}
\end{aligned}
$$

Tabel 9. Optimisasi Robust Spuit Terumo 5 mL

Sumber: Data diolah (2019)

\subsection{Analisis Jumlah Pemesanan Minimum dan Biaya Penyediaan melalui Model EOQ tanpa Stock Out, EOQ dengan Cadangan Penyangga, dan Optimisasi Robust}

Berdasarkan perhitungan pada masingmasing model pada bagian terdahulu, dapat dilihat bahwa jumlah pemesanan minimum yang diperoleh melalui model EOQ tanpa Stock Out dan model EOQ dengan Cadangan Penyangga hampir mendekati satu nilai. Akan tetapi, biaya penyediaan yang dikeluarkan lebih kecil jika menggunakan model EOQ dengan Cadangan Penyangga. Hal ini terjadi karena pada model EOQ dengan Cadangan Penyangga biaya kekurangan juga dipertimbangkan. Sedangkan, biaya kekurangan tidak dipergunakan dalam perhitungan untuk model EOQ tanpa Stock Out. Terakhir, pada Optimisasi Robust diperoleh hasil berbeda dari kedua model EOQ sebelumnya. Selain itu, biaya penyediaan yang dihasilkan lebih kecil sehingga diperoleh selisih yang cukup signifikan dibandingkan kedua model sebelumnya.

Berdasarkan studi kasus tersebut, berikut merupakan kelebihan dan kelemahan pada masing-masing model yang disajikan pada Tabel 10. 
Tabel 10. Kelebihan dan Kelemahan Untuk Setiap Model Persediaan

\begin{tabular}{|c|c|c|}
\hline $\begin{array}{c}\text { Model } \\
\text { Persediaan }\end{array}$ & Kelebihan & Kelemahan \\
\hline $\begin{array}{l}\text { EOQ } \\
\text { tanpa } \\
\text { Stock Out }\end{array}$ & $\begin{array}{l}\text { - Perhitungan yang } \\
\text { sederhana dan } \\
\text { mudah dipahami. }\end{array}$ & $\begin{array}{l}\text { - Tidak } \\
\text { memperhitung-kan } \\
\text { permintaan yang } \\
\text { berubah-ubah dan } \\
\text { biaya kekurangan } \\
\text { yang hendak } \\
\text { dikeluarkan. } \\
\end{array}$ \\
\hline $\begin{array}{l}\text { EOQ } \\
\text { dengan } \\
\text { Cadangan } \\
\text { Penyangga }\end{array}$ & $\begin{array}{l}\text { - Memperhitung- } \\
\text { kan permintaan } \\
\text { yang berubah- } \\
\text { ubah dengan } \\
\text { adanya cadangan } \\
\text { penyangga. } \\
\text { - Titik pemesanan } \\
\text { kembali jelas } \\
\text { diketahui dan } \\
\text { tidak terikat oleh } \\
\text { waktu. }\end{array}$ & $\begin{array}{l}\text { - Memerlukan } \\
\text { ketelitian dalam } \\
\text { perhitungan karena } \\
\text { menggunakan } \\
\text { iterasi. }\end{array}$ \\
\hline $\begin{array}{l}\text { Optimisasi } \\
\text { Robust }\end{array}$ & $\begin{array}{l}\text { - Dapat diketahui } \\
\text { biaya } \\
\text { penyimpanan dan } \\
\text { kekurangan } \\
\text { secara detail pada } \\
\text { setiap periode. } \\
\end{array}$ & $\begin{array}{l}\text { - Memerlukan } \\
\text { bantuan software } \\
\text { dalam perhitungan } \\
\text { karena terdapat } \\
\text { banyak fungsi } \\
\text { kendala. }\end{array}$ \\
\hline
\end{tabular}

\section{KESIMPULAN DAN SARAN}

\subsection{Kesimpulan}

Berdasarkan pembahasan sebelumnya, dapat disimpulkan jumlah pemesanan minimum dan biaya penyediaan untuk masing-masing Spuit yaitu: Melalui Model EOQ tanpa Stock Out, diperoleh jumlah pemesanan minimum untuk Spuit Terumo $3 \mathrm{~mL}$ sebanyak 2.834 unit dengan total biaya penyediaan sebesar Rp 206.822.333,55. Sedangkan, untuk Spuit Terumo $5 \mathrm{~mL}$ diperoleh jumlah pemesanan minimum sebanyak 3.313 unit dengan total biaya penyediaan sebesar Rp 345.427.395,62.

Melalui Model EOQ dengan Cadangan Penyangga (Buffer Stock), diperoleh jumlah pemesanan minimum untuk Spuit Terumo $3 \mathrm{~mL}$ sebanyak 2.834 unit dengan total biaya penyediaan sebesar Rp 206.737.651,76. Sedangkan, untuk Spuit Terumo $5 \mathrm{~mL}$ diperoleh jumlah pemesanan minimum sebanyak 3.314 unit dengan total biaya penyediaan sebesar $\mathrm{Rp}$ 345.311.086,29.

Melalui Model Optimisasi Robust, diperoleh jumlah pemesanan minimum yang berbeda untuk tiap periodenya. Hal ini terjadi pada kedua jenis Spuit yaitu Spuit Terumo $3 \mathrm{~mL}$ dan Spuit Terumo $5 \mathrm{~mL}$. Adapun biaya penyediaan yang dikeluarkan untuk Spuit Terumo $3 \mathrm{~mL}$ sebesar Rp 187.148.637,76 dan untuk Spuit Terumo 5
$\mathrm{mL}$ biaya penyediaan yang dikeluarkan sebesar Rp 303.381.986,39.

Jumlah pemesanan minimum yang diperoleh melalui model EOQ tanpa Stock Out dan model EOQ dengan Cadangan Penyangga hampir mendekati satu nilai. Akan tetapi, biaya penyediaan yang dikeluarkan lebih kecil jika menggunakan model EOQ dengan Cadangan Penyangga karena pada model tersebut biaya kekurangan juga dipertimbangkan. Sedangkan pada Model Optimisasi Robust diperoleh hasil berbeda dari kedua model EOQ sebelumnya dengan biaya penyediaan yang dihasilkan lebih kecil dibandingkan model-model sebelumnya. Kemudian, melalui model EOQ tanpa Stock Out, model EOQ dengan Cadangan Penyangga, dan model Optimisasi Robust diperoleh total biaya yang lebih kecil sekitar 10\% untuk Spuit Terumo $3 \mathrm{~mL}$ dan $8 \%$ untuk Spuit Terumo $5 \mathrm{~mL}$ dibandingkan dengan biaya penyediaan yang dikeluarkan oleh rumah sakit.

\subsection{Saran}

Pada penelitian ini, peneliti tidak mengkaji mengenai model terbaik yang dapat digunakan untuk menentukan jumlah pemesanan minimum dan biaya penyediaan. Untuk itu, peneliti serahkan ke pihak Rumah Sakit Umum Surya Husadha untuk memilih model yang menurut pihak tersebut adalah model yang terbaik. Saran untuk penelitian selanjutnya yaitu dapat menggunakan model lainnya dalam menentukan jumlah pemesanan minimum dan biaya penyediaan pada kasus persediaan.

\section{DAFTAR PUSTAKA}

Bahtiyar, L., 2015. SlideShare. [Online] Available at: https://www.slideshare.net/mobile/nslutfi90/j enis-spuit-dan-ukurannya-38505297

[Accessed 5 November 2018].

Ben-Tal, A., Ghaoui, L. E. \& Nemirovski, A., 2009. Robust Optimization. United States of Amerika: Princeton University Press.

Bertsimas, D. \& Thiele, A., 2006. A Robust Optimization Approach to Inventory Theory. Operation Research, 54(1), pp. 150-168.

Haming, M., Suriyanti, Ramlawati \& Imaduddin, 2017. Operation Research: Teknik Pengambilan Keputusan Optimal. 1 ed. Jakarta: Bumi Aksara.

Siagian, P., 2006. Penelitian Operasional: Teori dan Praktek. Kedua ed. Jakarta: Universitas Indonesia Press. 